\title{
Spatial and temporal changes of primary production in a deep peri-alpine lake
}

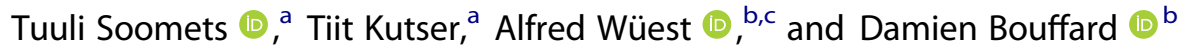 \\ ${ }^{a}$ Estonian Marine Institute, University of Tartu, Tallinn, Estonia; ${ }^{b}$ Eawag, Swiss Federal Institute of Aquatic Science and Technology, Surface \\ Waters - Research and Management, Kastanienbaum, Switzerland; 'Physics of Aquatic Systems Laboratory, Margaretha Kamprad Chair, \\ ENAC-IEE-APHYS, École Polytechnique Fédérale de Lausanne (EPFL), Lausanne, Switzerland
}

\begin{abstract}
Lake productivity is fundamental to biogeochemical budgets as well as estimating ecological state and predicting future development. Combining modelling with Earth Observation data facilitates a new perspective for studying lake primary production. In this study, primary production was modelled in the large Lake Geneva using the MEdium Resolution Imaging Spectrometer (MERIS) image archive for 2002-2012. We used a semi-empirical model that estimates primary production as a function of photosynthetically absorbed radiation and quantum yield of carbon fixation. The necessary input parameters of the model-concentration of chlorophyll $a$, downwelling irradiance, and the diffuse attenuation coefficient-were obtained from MERIS products. The primary production maps allow us to study decennial temporal (with daily frequency) and spatial changes in this lake that a single sample point cannot provide. Modelled estimates agreed with in situ results $\left(R^{2}=0.68\right)$ and showed a decreasing trend $(\sim 27 \%)$ in production in Lake Geneva for the selected decade. Yet, in situ monitoring measurements missed the general increase of productivity near the incoming Rhône River. We show that the temporal and spatial resolution provided by satellite observations allows estimates of primary production at the basin-scale. The phytoplankton annual primary production was estimated as $\sim 302$ (SD 20) $\mathrm{g} \mathrm{C} \mathrm{m}^{-2} \mathrm{yr}^{-1}$ for Lake Geneva for 2003 to 2011. This study demonstrates that maps of primary production can be obtained even with reduced resolution (1200 m) MERIS data and relatively simple methods, and thereby calls for deeper integration of remote sensing products into conventional in situ observation approaches.
\end{abstract}

\section{ARTICLE HISTORY}

Received 28 January 2018

Accepted 30 August 2018

\section{KEYWORDS}

bio-optics; Earth observation; Lake Geneva; MERIS; primary production; remote sensing

\section{Introduction}

Earth has more than 117 million lakes and reservoirs $>0.002 \mathrm{~km}^{2}$ (Verpoorter et al. 2014). These waterbodies comprise only $\sim 4 \%$ of the Earth's land surface, but they contain $\sim 85 \%$ of the global freshwater resource society relies on for drinking water, agriculture, fisheries, energy, transport, and landscape elements. Lakes are also important components of global biogeochemical cycles in their role in storage and transformation of carbon (Tranvik et al. 2009). They contribute significantly to climate regulation via the production and release of globally significant quantities of greenhouse gases (Tranvik et al. 2009, Bastviken et al. 2011, Raymond et al. 2013) and are recognized as valuable "sentinels" of global environmental change (Williamson et al. 2014).

Despite the importance of lakes, the lack of human and financial resources strongly hampers sufficient systematic and high frequency monitoring. Today, using satellite data for such high frequency monitoring is common, especially on land and open oceans (Kutser 2004, Klemas 2012). Monitoring lakes with satellites is more challenging because most lakes are optically complex. The concentrations of water constituents vary independently from each other and in wide ranges, leading to an illposed, inverse problem in which many combinations of water constituents can produce identical remote sensing signals (Defoin-Platel and Chami 2007). Developing remote sensing algorithms that perform well over a variety of lakes may be impossible, although approaches have been proposed in which lakes are first split into different classes, and class-specific algorithms are then applied as the second processing step (Spyrakos et al. 2018). Lake remote sensing has also been hampered by the absence of suitable sensors (Palmer et al. 2015). The technical situation (spectral and temporal resolution, optimum band choice, satellite revisiting time) has improved significantly in recent years with the launch of Landsat-8, Sentinel-2A and 2B (Toming et al. 2016), and Sentinel-3A and 3B. OLCI on-board Sentinel-3 is a follow-up sensor for MEdium Resolution Imaging Spectrometer (MERIS) and could therefore be used most effectively once MERIS analysis is completed. The usefulness of MERIS for remote sensing of different lake parameters, 
such as water transparency, biota, and lake hydrology, has been demonstrated in the past decade (Gons et al. 2008, Mishra and Mishra 2012, Odermatt et al. 2012, Augusto-Silva et al. 2014, Dörnhöfer and Oppelt 2016).

Rapid development of in situ sensors and platforms allows higher frequency measurements of fluorescence, turbidity, oxygen, and other parameters on moorings or even on autonomous underwater vehicles (AUVs), creating 3D scans of lake parameters (Cremona et al. 2016, Meinson et al. 2016). Still, some measurements that require lab work will remain difficult to carry out at high frequency, such as measuring phytoplankton primary production (PP). $\mathrm{PP}$ is crucial because it is the direct result of the photosynthesis and represents the sum of all photosynthetic rates in an ecosystem (Fee 1998). In large lakes, phytoplanktonic PP can represent a major input of new organic matter and potential energy that drives the ecosystem (Wetzel 2001). Remote sensing products could make a clear difference here by compensating the expensive and time-consuming measurements.

Studies estimating PP from light intensity and phytoplankton pigments with remote sensing in marine and ocean waters (Platt and Sathyendranath 1988, Smith et al. 1989, Woźniak et al. 1995, Siegel et al. 2001, Behrenfeld et al. 2005) have a long history compared with similar studies in large lakes (Arst et al. 2008, Bergamino et al. 2010, Shuchman et al. 2013, Fahnenstiel et al. 2016, Deng et al. 2017). The general aim of this study was to demonstrate the usefulness of remotely sensed data for monitoring spatiotemporal variations of phytoplankton PP in a lake. We used a model developed for large, wellmixed, shallow, and eutrophic lakes based on only satellite data as input (Arst et al. 2008, 2012, Kauer et al. 2009, 2013, 2015, Nõges et al. 2011). Studies that determine whether similar methods can be applied in deep stratified lakes are needed. We chose Lake Geneva as a test site because it is well studied and in situ PP estimates are available. We aimed to find the most accurate yet simplest way to quantify spatial and temporal variations of PP. Therefore, the specific objectives of this study were to (a) assess the performance of a semi-empirical PP model that uses input data from satellite products instead of in situ data; (b) study the spatial variability of PP; and (c) generate time series of PP from 2002 to 2012 by using the full MERIS image archive of Lake Geneva.

\section{Methods}

\section{Study site}

Lake Geneva (Lac Léman) is the largest lake in Western Europe. It is socioeconomically important because it provides freshwater for $>800000$ people. Lake Geneva covers
$580 \mathrm{~km}^{2}$, has an average and maximum depth of $154 \mathrm{~m}$ and $310 \mathrm{~m}$, respectively, and has 3 distinguishable basins: (1) Upper Lake (Haut Lac), the eastern part in front of the Rhône Delta; (2) Large Lake (Grand Lac), the widest and deepest basin; and (3) Small Lake (Petit Lac), the most southwest, narrowest, and shallowest part. Based on its physical, chemical, and biological characteristics, Lake Geneva is perceived as a meso-/eutrophic lake (or eutrophic, in the case of the Upper Lake). Lake Geneva receives water from various tributaries, with River Rhône as the primary contributor. The path of river waters into the lake is complex, typical for many perialpine lakes fed by glacier water. River water mixes only little with lake water in the surface layer because most of the sediment-rich river waters sink to deeper layers within $\sim 100 \mathrm{~m}$ from the river mouth and intrude into the lake waters, either into the thermocline or even deeper layers, initiating complex biogeochemical interactions along its path (Bouffard and Perga 2016).

\section{In situ measurements}

Chlorophyll $a$ (Chl-a) and PP are measured for the Commission International pour la Protection des Eaux du Léman (CIPEL) by scientists of INRA (a European scientific news source) year-round, typically twice (or at least once during the winter) per month. The monitoring station is in the middle of the lake $\left(46^{\circ} 27^{\prime} 09.4^{\prime \prime} \mathrm{N}\right.$, $\left.6^{\circ} 35^{\prime} 19.5^{\prime \prime} \mathrm{E}\right)$. Reports of the in situ monitoring are available at www.cipel.org.

PP was measured as the incorporation of ${ }^{14} \mathrm{C}$ by the phytoplankton (Steeman-Nielsen 1952) at 10 depth levels $(0$ to $30 \mathrm{~m})$. One dark and 2 light glass bottles $(120 \mathrm{~mL}$ each) were used at 10 fixed depths following a long-term monitoring program initiated in the 1960s. The incubation time was at midday for a duration corresponding to the "median third" of the photoperiod. The use of dark and transparent bottles allowed estimates of net PP. The measured PP was converted to daily production using a factor of 2.22 (Pelletier 1983). For interannual comparison, PP profile values were integrated in the $0-30 \mathrm{~m}$ surface zone. Annual net PP was estimated on the basis that the sample station represents $60 \%$ of the measured annual PP (i.e., gross output; www.cipel.org). Chl- $a$ was analyzed in a spectrophotometer using methodology by Strickland and Parsons (1968). Together with PP measurements, the transparency of the water was measured with a $30 \mathrm{~cm}$ diameter white Secchi disk $\left(Z_{\text {Secchi }}\right)$.

\section{Bio-optical primary production model}

We used a bio-optical model developed for estimating lake PP from remote sensing data (Kauer et al. 2013, 
2015). The basic equation of the semi-empirical model describes PP as a function of photosynthetically absorbed radiation and quantum yield of $\mathrm{C}$ fixation (Smith et al. 1989, Arst et al. 2008):

$$
\operatorname{PP}(z)=\Psi Q_{\mathrm{PAR}}^{*}(\mathrm{z}) F_{\mathrm{PAR}}(z),
$$

where $\Psi$ is the factor 12000 for converting moles to milligrams of $\mathrm{C} ; Q^{*}{ }_{\mathrm{PAR}}(z)$ is the photosynthetically absorbed radiation at depth $z$ (mol photons $\mathrm{m}^{-3} \mathrm{~h}^{-1}$ ) determined on the basis of scalar quantum irradiance; and $F_{\mathrm{PAR}}(z)$ is the quantum yield of $\mathrm{C}$ fixation (mol C (mol photons $)^{-1}$ ) in the photosynthetically active radiation (PAR) range of $400-700 \mathrm{~nm}$.

We used equations $2-10$ to determine $Q^{*}{ }_{\mathrm{PAR}}(z)$ :

$$
Q_{P A R}^{*}(z) \approx C(z) Q_{P A R}(z) .
$$

Here, $C(z)$ is a correction factor between scalar and planar photosynthetically absorbed radiation, and $Q_{\mathrm{PAR}}(z)$ is photosynthetically absorbed radiation at depth $z$ based on planar quantum irradiance (mol photons $\left.\mathrm{m}^{-3} \mathrm{~h}^{-1}\right) . C(z)$ was determined using the Chl- $a$ concentration $C_{\mathrm{chl}}\left(\mathrm{mg} \mathrm{m}^{-3}\right)$ and the light attenuation coefficient $K_{\mathrm{d}, \mathrm{PAR}}\left(\mathrm{m}^{-1}\right)$ values (Arst et al. 2008) according to equations 3-5:

$$
C(z)=C_{1} \exp \left(C_{2} z\right)
$$

where

$$
\begin{gathered}
C_{1}=1.32 K_{\mathrm{d}, \mathrm{PAR}}^{0.153} \text {, and } \\
C_{2}=0.0023 C_{\mathrm{chl}}+0.016 .
\end{gathered}
$$

The main formula to calculate $Q_{\mathrm{PAR}}(z)$ was:

$$
Q_{P A R}(z) \approx q_{\mathrm{PAR}}(z) a_{\mathrm{ph}, \mathrm{PAR}},
$$

where $q_{\mathrm{PAR}}(z)$ is the planar quantum irradiance at depth $z$ in the PAR region. We used the well-known equation:

$$
q_{\mathrm{PAR}}(z)=q_{\mathrm{PAR}}(-0) \exp \left(-K_{\mathrm{d}, \mathrm{PAR}} z\right),
$$

where $q_{\mathrm{PAR}}(-0)$ is the incident planar quantum irradiance just below the water surface, and

$$
q_{\mathrm{PAR}}(-0)=(1-0.06) q_{\mathrm{PAR}}(+0),
$$

where 0.06 is the mean albedo of the water surface. The second parameter in equation $6, a_{\mathrm{ph}, \mathrm{PAR}}$, is an average of the specific absorption coefficient of phytoplankton, $a_{p h}^{\prime}$ in $\mathrm{m}^{2} \mathrm{mg}^{-1}$, across wavelengths in the range of $400-$ $700 \mathrm{~nm}$, calculated using equation 9:

$$
a_{p h, P A R}=\frac{\int_{400}^{700} a_{p h}^{\prime}(\lambda) C_{c h l} d \lambda}{\int_{400}^{700} d \lambda} .
$$

For the absorption coefficient of phytoplankton, $a_{p h}^{\prime}$, an algorithm with wavelength-dependent coefficients $A$ and $B$ from Stæhr and Markager (2004) was used:

$$
a_{p h}^{\prime}(\lambda)=A(\lambda) C_{\mathrm{chl}}^{-B(\lambda)} .
$$

The second parameter of equation $1, F_{\mathrm{PAR}}(\mathrm{z})$, was calculated according to equation 11 :

$$
F_{P A R}(z)=\frac{F_{\max }}{\left(1+M q_{P A R}(z)\right)^{1.5}},
$$

where $F_{\max }=0.08 \mathrm{~mol} \mathrm{C}$ (mol photons) ${ }^{-1}$, and $M$ is the parameter that can depend on incident irradiance as well as on the bio-optical characteristics of the waterbody. In this study we used algorithms by Arst et al. (2012) to calculate $M$ according to the $C_{\mathrm{chl}}$ values:
a) if $C_{\mathrm{chl}}<35 \mathrm{mg} \mathrm{m}^{-3}$, then $M=3.18-0.2125 K_{d, P A R}^{2.5}+0.34 q_{\mathrm{PAR}}(+0)$;
b) if $C_{\mathrm{chl}} \geq 35$ and $<80 \mathrm{mg} \mathrm{m}^{-3}$, then $M=3.58-0.31 q_{\mathrm{PAR}}(+0)-0.0072 C_{\mathrm{chl}}$;
c) if $C_{\mathrm{chl}} \geq 80$ and $\leq 120 \mathrm{mg} \mathrm{m}^{-3}$, then $M=2.46-0.106 q_{\mathrm{PAR}}(+0)-0.00081 C_{\mathrm{chl}}^{1.5}$; and d) if $C_{\mathrm{chl}}>120 \mathrm{mg} \mathrm{m}^{-3}$, then $M=0.67$.

The model, originally intended for optically complex well-mixed lakes, requires 3 input parameters: (1) Chl- $a$ concentration $C_{\mathrm{chl}}\left(\mathrm{mg} \mathrm{m}^{-3}\right)$; (2) incident planar downwelling irradiance (in mol photons $\mathrm{m}^{-2} \mathrm{~h}^{-1}$ ); and (3) the underwater light diffuse attenuation coefficient, $K_{\mathrm{d} \text {,PAR }}\left(\mathrm{m}^{-1}\right)$. In this study, we used the latest version of the integral model (Arst et al. 2012), performing a new quantification of the model with updated spectra of the specific absorption coefficient of light by phytoplankton $\left(C_{\mathrm{chl}}\right.$ in the test database varied from 0.03 to $\left.88.1 \mathrm{mg} \mathrm{m}^{-3}\right)$. Despite the simplicity of the semiempirical models, the comparison of measured and modelled PP yielded a coefficient of determination, $R^{2}$, in the range of $0.79-0.96$, and $p$ was always $<0.00001$. The quantification of the model was conducted in meso- or eutrophic lakes in which the concentrations of Chl- $a$ ranged from 4 to $389 \mathrm{mg} \mathrm{m}^{-3}$. The details of the model are explained in previous studies by Arst et al. $(2008,2012)$ that describe the development of this model.

The Chl- $a$ values in the model equations 4-10 were taken either as the measured values of CIPEL or the satellite data products. For the $K_{\mathrm{d}, \mathrm{PAR}}$ values, we used a conversion from Secchi depth (equation 12 by Holmes 1970, Schwefel et al. 2016) for in situ inputs, and for satellite data inputs used the $K_{\mathrm{d}, 490}$ product (equation 13 by 
Table 1. Maximum daily PAR irradiance ${ }^{\mathrm{a}}$ for Lake Geneva.

\begin{tabular}{lllllll}
\hline Month & Jan & Feb & Mar & Apr & May & Jun \\
\hline $\begin{array}{l}\text { Irradiance, } \mu \mathrm{mol} \\
\text { photons } \mathrm{m}^{-2} \mathrm{~h}^{-1}\end{array}$ & 397 & 634 & 979 & 1179 & 1217 & 1336 \\
\hline Month & Jul & Aug & Sep & Oct & Nov & Dec \\
\hline $\begin{array}{l}\text { Irradiance, } \mu \mathrm{mol} \\
\text { photons } \mathrm{m}^{-2} \mathrm{~h}^{-1}\end{array}$ & 1402 & 1282 & 1079 & 730 & 447 & 323 \\
$\begin{array}{l}\text { awww.soda-pro.com } \\
\text { wwoda }\end{array}$ & & & & & & \\
\hline
\end{tabular}

Morel et al. 2007):

$$
\begin{aligned}
& K_{\mathrm{d}, \mathrm{PAR}}=\frac{1.44}{Z_{\text {Secchi }}} \text { and } \\
& K_{\mathrm{d}, \mathrm{PAR}}= 0.0864+0.884 \times K_{\mathrm{d}, 490} \\
&-\left(\frac{0.00137}{K_{\mathrm{d}, 490}}\right) .
\end{aligned}
$$

For incoming irradiance, we used a PVGIS-CMSAF solar radiation database (www.soda-pro.com). From the average daily solar irradiance estimates of Lake Geneva, a maximum daily global irradiance $\left(\mathrm{W} \mathrm{m}^{-2}\right)$ for each month was selected and converted to PAR incident irradiance ( $\mu$ mol photons $\mathrm{m}^{-2} \mathrm{~h}^{-1}$; Table 1 ).

For daily PP calculations, the hourly production was multiplied by photoperiod (in $\mathrm{h}$ ) and by the coefficient 0.75 ; because of the daily light curve, maximum daily incoming irradiance cannot be applied throughout the photoperiod. For the monthly PP estimations, the missing days, due to absent overpasses of the satellite or cloudy images, were calculated by interpolation, and all days were summarized. Annual estimates were obtained by summarizing the monthly estimates.

For the entire lake PP temporal integration, we included images with $\geq 50 \%$ of the lake pixels. All missing lake pixels were taken as the average of the available pixels of a given day. To calculate the daily, monthly, and yearly productions, previously described methods were applied.

\section{Satellite data}

The 3 necessary input parameters were obtained from MERIS-appropriate products over the entire mission (2002-2012). Reduced resolution (each image pixel represents an area of $1040 \times 1160 \mathrm{~m}$ ) satellite images were obtained from 2 different databases: Optical Data Processor of the European Space Agency (ODESA; http:// www.odesa-info.eu/process_basic/basic.php) and the CoastColour Calvalus Portal (http://www.coastcolour. org/ccprocessing/calvalus.jsp).

We used 6 different processors to determine the best input parameters for Lake Geneva: (1) MERIS standard Level 2 processing, MEGS 8.1 (MEGS; Morel and Antoine 2011); (2) Lakes Processors (Boreal and Eutrophic; Doerffer and Schiller 2008); (3) Case-2 Regional algorithm (C2R,
Doerffer and Schiller 2007); (4) CoastColour OC4 (Morel and Antoine 2011); (5) Free University Berlin (FUB) processor (Schroeder et al. 2007); and (6) Maximum Chlorophyll Index (MCI; Gower et al. 2005). These processors are different imagery-treating tools that use the water-leaving reflectance as input and compute different water quality products. After determining Chl- $a$ products with all 6 processors and comparing them with in situ results, we chose the best performing processor to continue the analysis.

For $K_{\mathrm{d}, \mathrm{PAR}}$, as the second input parameter, we used the model (equation 13) described in Morel et al. (2007) using $K_{\mathrm{d}, 490}$ product from CoastColour L2 processing.

\section{Results}

\section{Validation of the model}

Over the decade of MERIS operational time (May 2002 to April 2012), 192 in situ PP measurements have been carried out in Lake Geneva. During that period, 42 measurements had a same-day satellite overpass with a matching cloud-free MERIS image. The nearest pixel to the in situ sampling point was taken from each image.

The PP model calculations were performed with products of 6 different MERIS processors. We present only the best results in this paper. The best performer for Chl- $a$ was CoastColour OC4 processor $\left(R^{2}=0.56 ; n=\right.$ 42; Fig. 1a, Table 2). MEGS algal_1 also showed good correlation $\left(R^{2}=0.53 ; n=21\right)$, but this algorithm gave results on only half of the match-up days.

To estimate the in situ $K_{\mathrm{d}, \mathrm{PAR}}$ in Lake Geneva we used the relationship between $K_{\mathrm{d} \text {,PAR }}$ and Secchi depth (equation 12), and for satellite-derived $K_{\mathrm{d}, \mathrm{PAR}}$ estimates we used $K_{\mathrm{d}, 490}$ products from the CoastColour processor (equation 13). We compared the in situ and estimated $K_{\mathrm{d}, \mathrm{PAR}}$ (Fig. 1b) and identified some statistical parameters (Table 2), but this additional calculation added little to the results. The difference between $K_{\mathrm{d}, \mathrm{PAR}}$ and $K_{\mathrm{d}, 490}$ products compared with in situ $K_{\mathrm{d} \text {,PAR }}$ were minor $\left(R^{2}\right.$ values were the same in the current study; mean absolute percentage error [MAPE] was $40.3 \%$ and $36.3 \%$, respectively; and systematic error [BIAS] was 0.004 and $-0.049 \mathrm{~m}^{-1}$, respectively). This result was previously demonstrated by Kauer et al. (2015). Only remote sensing data with in situ match-ups were used for the PP model and compared and summarized (Fig. 1c, Table 2).

The measured profiles of PP in Lake Geneva were compared with modelled PP profile results (Fig. 2). In general, the model fits the PP profiles well, although the vertical structure of PP can have complex shapes that are difficult to model. Interestingly, integral PP $\left(\mathrm{PP}_{\text {int }}\right)$ can be highly accurate, despite the disagreements in the vertical structure of the profile of PP (Fig. 2). 

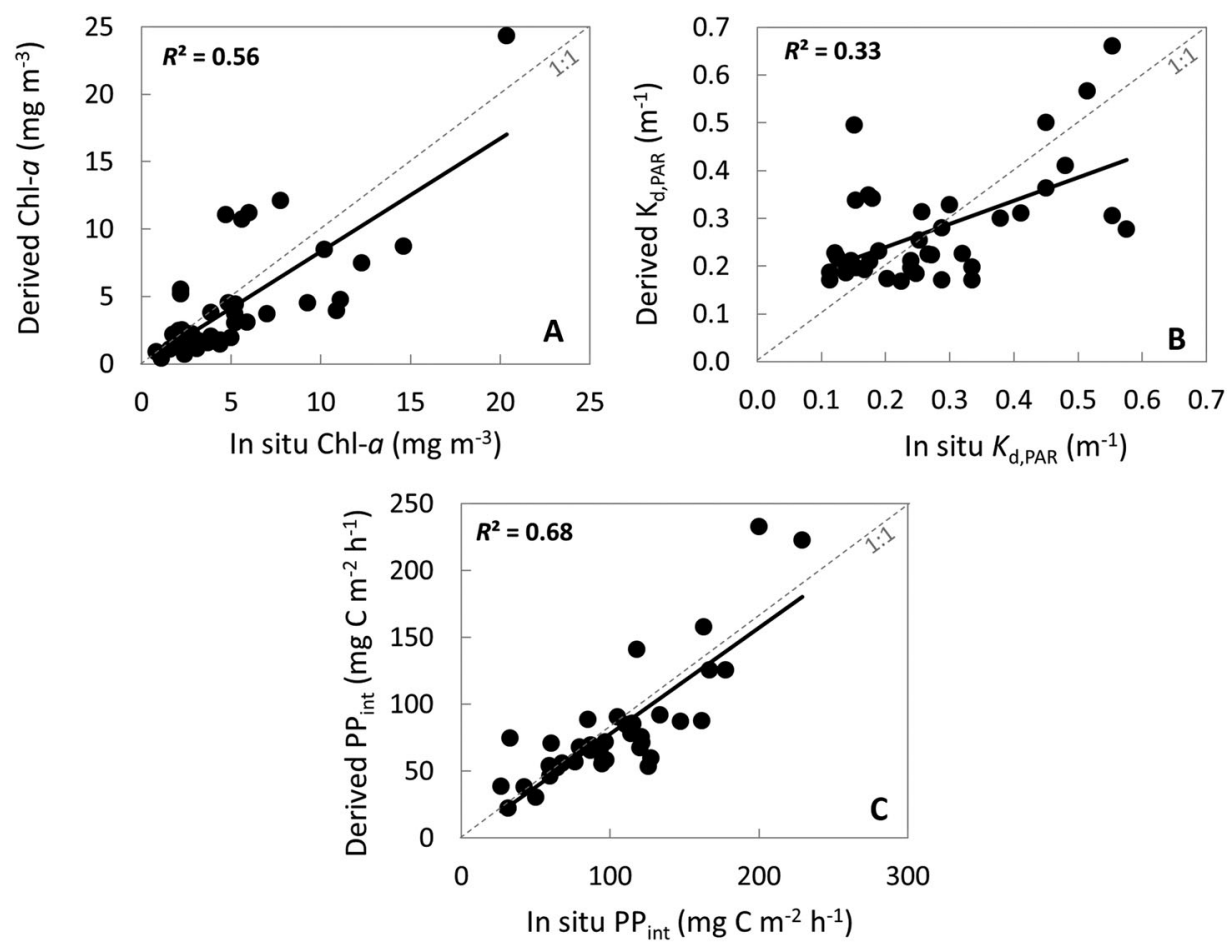

Figure 1. Comparison of (a) MERIS-derived and in situ sampled Chl- $a$; (b) MERIS-derived and in situ $K_{\mathrm{d} ; \mathrm{PAR}}$; and (c) satellite-based and in situ $\mathrm{PP}_{\text {int }}$ in Lake Geneva on match-up days.

When comparing the profiles, the incoming irradiance is crucial in the modelled profiles because it is affected by low illumination conditions during the in situ measurements. For every month during this study, a maximum daily PAR irradiance was used (Table 1) instead of in situ incoming irradiance.

\section{Spatial and temporal variability of primary production}

We generated $1122 \mathrm{PP}_{\text {int }}$ maps from 2252 MERIS images. Lake Geneva has spatial variations perennially, and therefore one measuring point in the middle of the lake does not represent the entire lake (Fig. 3). The same conclusion was drawn by Kiefer et al. (2015) in their studies of the Chl- $a$ distribution.

Lake Geneva has high variability in the spatial distribution of PP (the mean over the entire study period $\mathrm{PP}_{\text {int }}$ was 86 [SD 113] $\mathrm{mg} \mathrm{C} \mathrm{m}^{-2} \mathrm{~h}^{-1}$ ). In more extreme cases, the $\mathrm{PP}_{\text {int }}$ range can reach $900 \mathrm{mg} \mathrm{C} \mathrm{m}^{-2} \mathrm{~h}^{-1}$ within a lake (Table 3). Generally, higher PP occurs near the main inflow of the River Rhône (in Upper Lake), yet Small Lake (western part) commonly has a higher PP than Upper Lake.

In addition to the spatial information, satellite images provide high temporal frequency data (for cloud-free weather). Therefore, using remote sensing allows monitoring short time events, such as phytoplankton blooms that could be missed by regular in situ monitoring (Kiefer et al. 2015). An example of such a phytoplankton bloom in March 2012 (Fig. 4) showed that, as typical for this lake, the bloom started from the east part of the lake. The biggest change was observed between 21 and 24 March, when the bloom developed rapidly along the southern coast to Small Lake, where PP became even higher than in Upper Lake. By 1 April, the entire lake doubled its productivity within 3 weeks (Fig. 4). Two in situ measurements were carried out during that time, yielding a $\mathrm{PP}_{\text {int }}$ of $68 \mathrm{mg} \mathrm{C} \mathrm{m}^{-2} \mathrm{~h}^{-1}$ on 8 March and $150 \mathrm{mg} \mathrm{C} \mathrm{m}^{-2} \mathrm{~h}^{-1}$ on 19 March.

Table 2. Statistical parameters (coefficient of determination $\left[R^{2}\right]$, root mean square error [RMSE], systematic error [BIAS], mean absolute percentage error [MAPE], probability value $\left[P\right.$-value]) of modelled primary production $\mathrm{PP}_{\mathrm{int}}, \mathrm{Chl}-a_{\text {, }}$ and diffuse attenuation coefficient $K_{\mathrm{d}}$ from CoastColour (CC) products. $n$ marks the number of match-ups used.

\begin{tabular}{|c|c|c|c|c|c|c|c|}
\hline & $n$ & Regression & $R^{2}$ & RMSE & BIAS & MAPE & $P$-value \\
\hline Modelled $\mathrm{PP}_{\text {int }}\left(\mathrm{mg} \mathrm{C} \mathrm{m}^{-2} \mathrm{~h}^{-1}\right)$ & 42 & $y=0.79 x-1.48$ & 0.68 & 34.54 & -22.85 & 29.52 & $<0.00001$ \\
\hline $\mathrm{Chl}-a\left(C C\right.$ OC4) $\left(\mathrm{mg} \mathrm{m}^{-3}\right)$ & 42 & $y=0.84 x-0.05$ & 0.56 & 3.14 & -0.89 & 49.89 & $<0.00001$ \\
\hline$K_{\mathrm{d}, \mathrm{PAR}}(\mathrm{CC})\left(\mathrm{m}^{-1}\right)$ & 42 & $y=0.49 x+0.14$ & 0.33 & 0.12 & 0.004 & 40.26 & 0.00012 \\
\hline
\end{tabular}



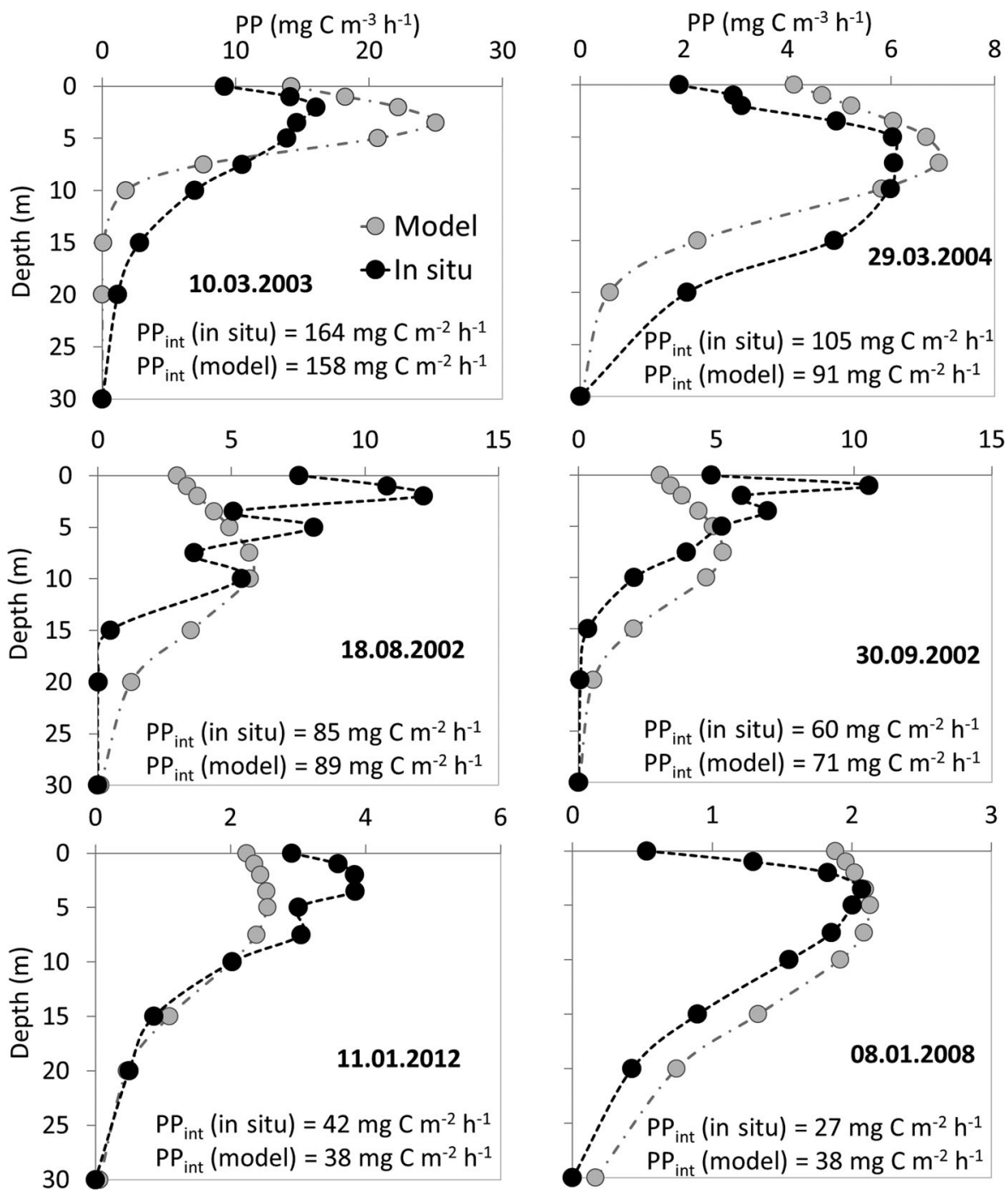

Figure 2. Comparison of selected samples of the measured and modelled PP profiles $\left(\mathrm{mg} \mathrm{C} \mathrm{m}^{-3} \mathrm{~h}^{-1}\right)$ and PP int $\left(\mathrm{mg} \mathrm{C} \mathrm{m}^{-2} \mathrm{~h}^{-1}\right)$ in Lake Geneva. Panels are ordered according to decreasing productivity.

To analyze the trends in the lake over the MERIS mission time (2002 to 2012), we added 2 points of observation (East and West points) to Upper and Small lakes, accordingly, located at the corners of the French and Swiss border in the lake (East point coordinates $46^{\circ} 25^{\prime} 37.9^{\prime \prime} \mathrm{N}, 6^{\circ} 49^{\prime} 15.1^{\prime \prime} \mathrm{E}$; West point $46^{\circ} 18^{\prime} 42.9^{\prime \prime} \mathrm{N}$, $6^{\circ} 13^{\prime} 10.2^{\prime \prime} \mathrm{E}$; Fig. 5, upper-right corner). The Centre point is the in situ monitoring station in Large Lake $\left(46^{\circ} 27^{\prime} 09.4^{\prime \prime} \mathrm{N}, 6^{\circ} 35^{\prime} 19.5^{\prime \prime} \mathrm{E}\right)$.

The average annual production over 10 years (May 2002 to March 2012) was estimated as 245 [SD 68] $\mathrm{g} \mathrm{C} \mathrm{m}^{-2} \mathrm{yr}^{-1}$ (at Centre point), 263 [43] $\mathrm{g} \mathrm{C} \mathrm{m}^{-2} \mathrm{yr}^{-1}$ (at East point), and 203 [38] $\mathrm{g} \mathrm{C} \mathrm{m}^{-2} \mathrm{yr}^{-1}$ (at West point). The difference between the East and West points was $59 \mathrm{~g} \mathrm{C} \mathrm{m}^{-2} \mathrm{yr}^{-1}$ ( $23 \%$ ) of an average annual production (Fig. 5).

The lake demonstrated inner-annual seasonal variations (Fig. 5). In winter the entire lake had lower productivity, yet, interestingly, PP only dropped by a factor of $\sim 2$ in winter despite the much colder lake conditions and weaker solar radiations. The West point exhibited a significantly lower productivity than the rest of the lake while the East point had a generally higher productivity. Therefore, a noticeable longitudinal productivity gradient existed between the western and eastern part of the lake, possibility due to the River Rhône inflow, where $75 \%$ of the lake water and most of the phosphorus originates.

A decisive advantage of remote sensing data is the ability to calculate the total surface area integrated production over the entire lake, taking into account all available pixels, not only single points. The mean total annual $\mathrm{PP}_{\text {int }}$ of the lake for the entire period from 2003 to 2011 was 175 [SD 12] $\mathrm{Gg} \mathrm{C} \mathrm{yr}^{-1}$, or 302 [20] $\mathrm{g} \mathrm{C} \mathrm{m}^{-2} \mathrm{yr}^{-1}$ (Fig. 6).

We compared satellite with in situ estimates based on single station measurements (Fig. 6). Black dots mark the in situ estimates for annual PP, grey dots mark the PP 

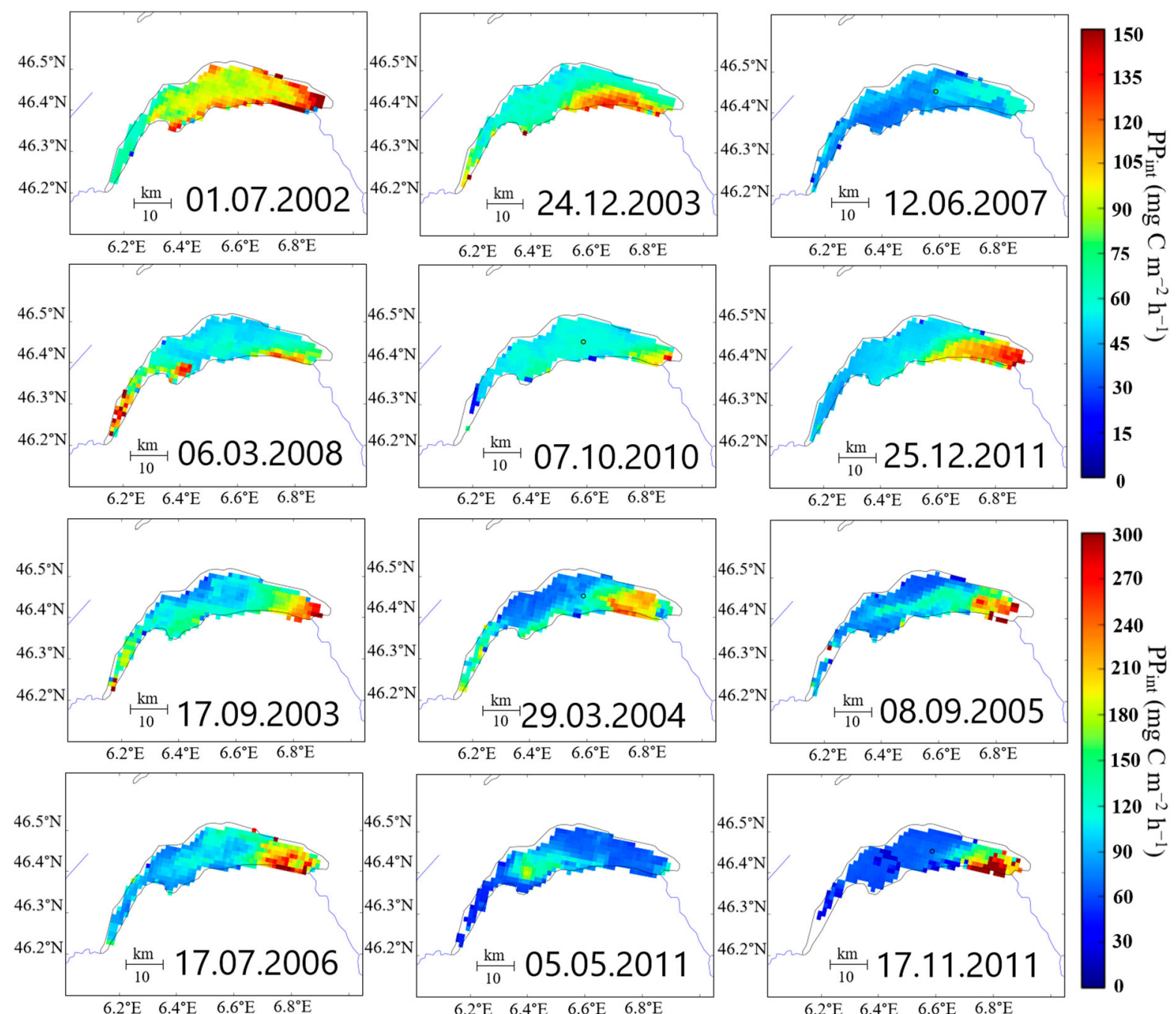

Figure 3. Selected samples of spatial variations of $\mathrm{PP}_{\mathrm{int}}\left(\mathrm{mg} \mathrm{C} \mathrm{m}^{-2} \mathrm{~h}^{-1}\right)$ in Lake Geneva. Circle represents the in situ measurement (on 4 match-up days). Note the difference in the maximum $\mathrm{PP}_{\text {int }}$ values between upper and lower 2 rows of sub-figures.

based on satellite data from Centre point, and white dots mark the PP based on satellite data including all the lake pixels. In general, the annual production estimates closely agreed with the annual PP estimates from Centre point. The error in estimating annual production during the study period was $23 \%$ (SD 9\%; MAPE $=22.9$; root mean square error $[\mathrm{RMSE}]=70.4$; BIAS $=17.2 \mathrm{~g} \mathrm{C} \mathrm{m}^{-2}$ $\mathrm{yr}^{-1}$ ). The trend line of annual PP is decreasing for both in situ and remote sensing estimates, with a faster decrease (slope $=11.1 \mathrm{~g} \mathrm{C} \mathrm{m}^{-2} \mathrm{yr}^{-2}$ ) for satellite

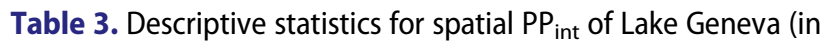
$\mathrm{mg}\left(\mathrm{m}^{-2} \mathrm{~h}^{-1}\right)$. SD = standard deviation. Parameters shown for entire observation period (May 2002 to April 2012) and for 2 example dates.

\begin{tabular}{llcccc}
\hline & Mean & Median & SD & Range & Confidence \\
\cline { 2 - 5 } & \multicolumn{3}{c}{$\mathrm{PP}_{\text {int }}$ in $\mathrm{mg} \mathrm{C} \mathrm{m}^{-2} \mathrm{~h}^{-1}$} & & level $95 \%$ \\
\hline May 2002 to Apr 2012 & 85.8 & 59.9 & 113 & 1090 & 3.9 \\
22 Oct 2003 & 203 & 174 & 120 & 877 & 12.3 \\
23 May 2011 & 39.7 & 38.7 & 7.2 & 50.5 & 0.7 \\
\hline
\end{tabular}

estimates because of the absence of peaks in 2007 and 2009 (Fig. 6). Years 2002 and 2012 were removed from the comparison because of the incomplete set of imagery.

The comparison of the satellite-based results (with all pixels) and the in situ estimates showed that the difference in estimating the annual production of the lake is $19 \%(\mathrm{SD} 6 \% ; \mathrm{MAPE}=19 ; \mathrm{RMSE}=68.3 ; \mathrm{BIAS}=39.9 \mathrm{~g}$

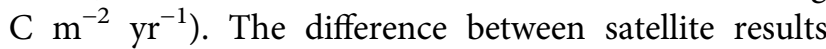
(from single point extrapolation and all pixels, grey and white dots on Fig. 6, accordingly) was approximately the same, $18 \%$ (SD 5\%; MAPE $=18.5 ; \mathrm{RMSE}=63.7$; BIAS $\left.=57 \mathrm{~g} \mathrm{C} \mathrm{m}^{-2} \mathrm{yr}^{-1}\right)$. Underestimation is similar in all years from Centre point, except during 2007 and 2009, where the center of the lake accurately represented the entire lake. The trend line of all pixels follows the same decline as the production obtained from Centre point. The decrease in PP over the 9 years was $\sim 27 \%$ (from 2003 to 2011, $100 \mathrm{~g} \mathrm{C} \mathrm{m}^{-2} \mathrm{yr}^{-1}$ ). 


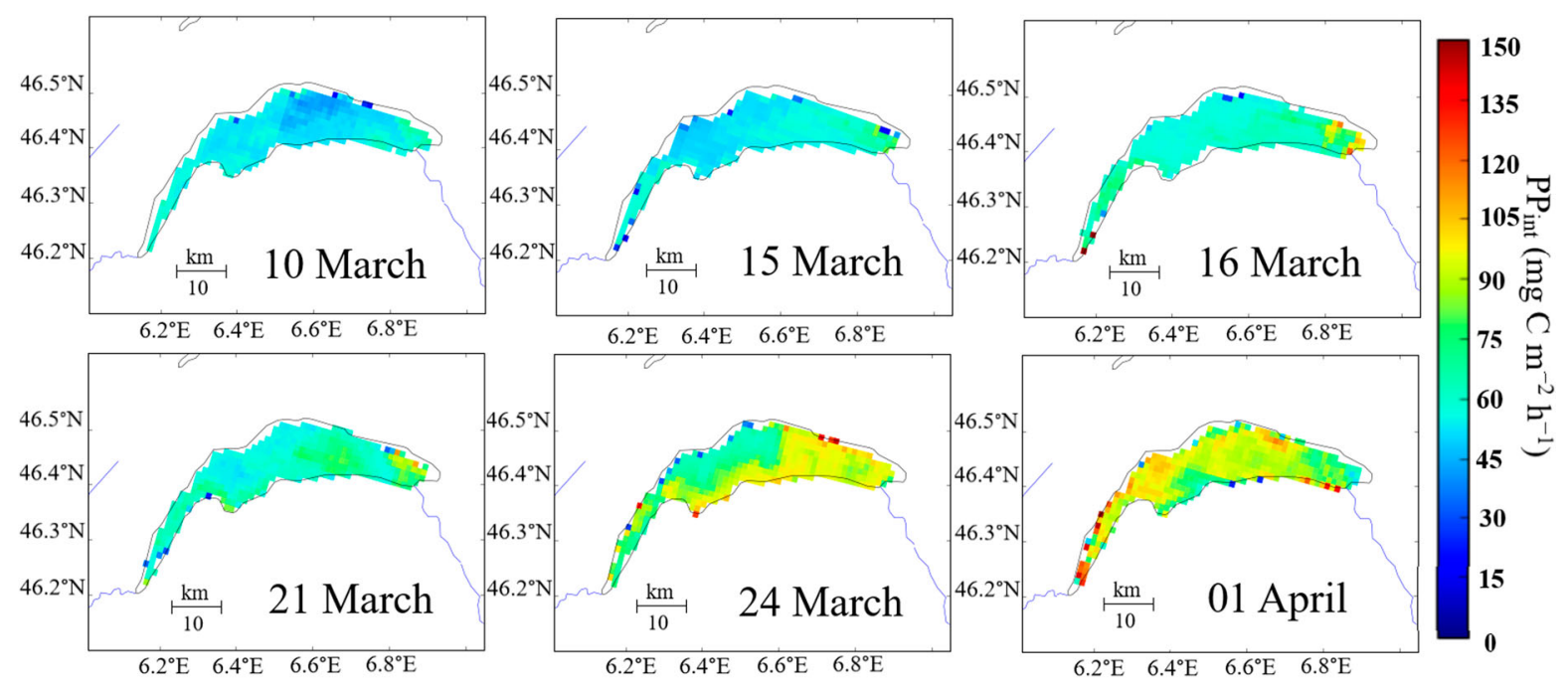

Figure 4. Development of a spring phytoplankton bloom $\left(\mathrm{PP}_{\mathrm{int}}, \mathrm{mg} \mathrm{C} \mathrm{m}^{-2} \mathrm{~h}^{-1}\right)$ in 2012.

\section{Discussion}

Overall, the CoastColour OC4 was the best performing algorithm of the 6 we tested (Table 2, Fig. 1a). The results of this study can immediately be extended to OLCI data to allow studies on long-term trends in lake PP. Unlike MERIS (a technical demonstration mission), the Sentinel missions are planned and funded for decades to come. We used reduced resolution (1200 m) MERIS data, but the study can be extended to full resolution (300 m) OLCI data, which will allow estimating PP in smaller lakes. The model results could be further improved if more suitable algorithms for deriving $K_{\mathrm{d}, 490}$ were developed (Fig. $1 \mathrm{~b}$ ). Testing wide ranges of different $K_{\mathrm{d}}$ algorithms was not our main goal because in situ $K_{\mathrm{d}}$ data were lacking.

The relationship between the in situ and modelled PP with satellite products were satisfactory $\left(R^{2}=0.68\right.$; Fig. 1c), especially because the model used is a simple

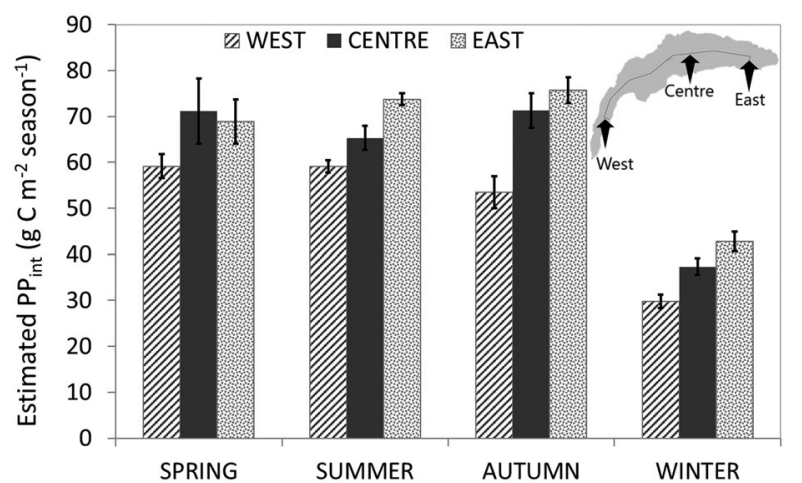

Figure 5. Estimated seasonal primary production $\left(\mathrm{PP}_{\mathrm{int}}, \mathrm{g} \mathrm{C} \mathrm{m}^{-2}\right.$ season $^{-1}$ ) and error bars at 3 observation points in Lake Geneva. Upper-right corner: Lake Geneva and 3 observation points (West, Centre, and East) of the study. semi-empirical model developed for turbid unstratified lakes. The model calculates PP profiles over depth, and the integral productivity was calculated from the PP profiles, allowing us to compare the calculated PP profiles with the measured profiles (Fig. 2). Based only on the incoming light, $C_{\mathrm{chl}}$, and $K_{\mathrm{d}}$ in water, the model accurately replicated the measured PP profiles. One reason the model, which is intended for well-mixed waters, worked well in stratified Lake Geneva could be that the nutrients are homogeneously distributed along the euphotic zone, which is often shallower than the depth of the thermocline. A small gradient of nutrients (increasing with depth) might explain deeper PP peaks. In addition, the river intrusion in the thermocline is a nutrient source in Upper Lake (CIPEL; www.cipel.org).

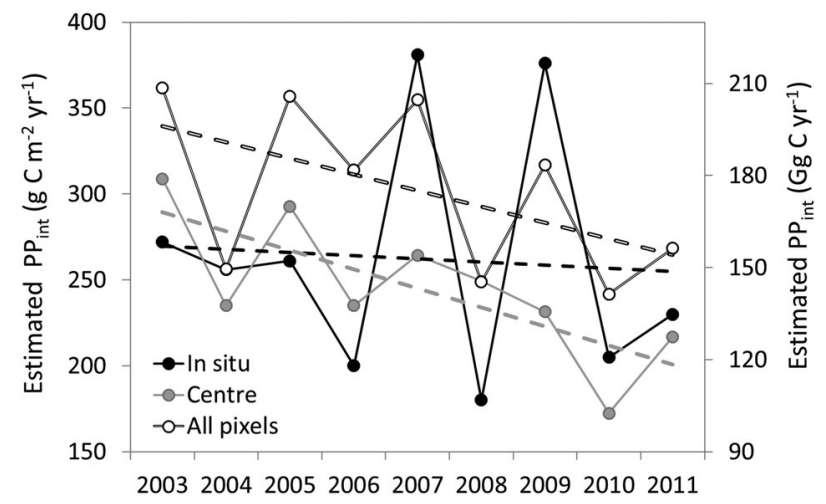

Figure 6. Estimated annual primary production $\left(\mathrm{PP}_{\mathrm{int}}, \mathrm{g} \mathrm{C} \mathrm{m}^{-2}\right.$ $\mathrm{yr}^{-1}$ ) in Lake Geneva from 2003 to 2011. Black: in situ estimation; grey: satellite data from Centre point; and white: satellite data including all the available lake pixels; the secondary $y$-axis shows the values of total annual primary production $\left(\mathrm{PP}_{\mathrm{int}}, \mathrm{Gg}\right.$ $\left(\mathrm{yr}^{-1}\right)$ and is marked with white dots. Parallel to the decline in $\mathrm{PP}$, the phosphorus content in the lake decreased from 32 (in 2003) to 22 (in 2010) $\mathrm{mg} \mathrm{m}^{-3}$. 
No other PP modelling study has been conducted in Lake Geneva based solely on Earth Observation data, and we therefore cannot compare current results. However, a study on Earth Observation on Lake Geneva $C_{\mathrm{chl}}$ (Kiefer et al. 2015) found $R^{2}$ values between satellite estimates and in situ Chl- $a$ observations approximately similar to those in our current study (0.62 vs. 0.56$)$. The stratus cloud conditions are often characteristic of the Swiss Plateau in late autumn and winter, and they strongly affect the ability to monitor the lake with remote sensing during this period. The lack of cloud-free imagery can also influence the results of monthly PP estimates, and in the worst cases only a few images can be used; however, the number of suitable dates per months ( 10) still exceeds the number of monthly in situ sampling periods (1 or 2). The number of cloud-free dates is low in winter, but PP during this period is not as important as in spring and summer in Lake Geneva.

Satellites provide details at both temporal and spatial scales that classic in situ monitoring data cannot achieve (Fig. 3 and 4). The PP maps generated clearly show that one measuring station does not accurately represent the entire lake, and more in situ sampling stations or the use of remote sensing are needed to estimate PP over the whole lake because its lateral variability (SD $113 \mathrm{mg}$ $\mathrm{C} \mathrm{m}^{-2} \mathrm{~h}^{-1}$ ) is large. The east to west gradient in productivity, where Upper Lake is more productive than in the rest of the lake, is probably due to the nutrient input from the main tributaries River Rhône. Yet, the pattern can change over time, and Small Lake can become more productive, as occurred during April 2012 (Fig. 4). For example, higher productivity in Upper Lake can occur when the bloom is ending, but it peaks in Small Lake (Fig. 4; 01 April 2012) because of its frequent upwelling events (Bouffard et al. 2018). Another disruption from the general trend can be observed with PP increasing only in Small Lake and Upper Lake. Nevertheless, the general trend indicates that Small Lake has a significantly lower PP than the rest of the lake (Fig. 5).

The annual estimates of PP by in situ and satellite data at the center are in close agreement (Fig. 6, black and grey dots), except for 2007 and 2009 when annual in situ PP was estimated almost double the average. In situ measurements were probably carried out during phytoplankton biomass peaks, resulting in higher than actual annual production. A clear decreasing trend in PP of the modelled data occurred during the study period (evident in the center and also in the entire lake, when all the lake pixels are included; Fig. 6). Unexpectedly, Kiefer et al. (2015) found the same trends $(\sim 27 \%)$ in the surface values of Chl- $a$ and phosphate concentrations in the center of the lake and in the outflows of the northern coast for 2002 to 2010 .
Modelled estimates might be lower in those years because the in situ measurements were taken during periods of high peaks that would overestimate the annual results, and/or they are not correctly capturing the $C_{\mathrm{chl}}$ of Mougeotia gracillima from the deeper layers of the lake. Years 2007 and 2009 were indeed characterized by unusually strong deep-biomass accumulation events. Mougeotia gracillima tolerates low light conditions and can grow in deeper layers (Reynolds 2006). These deep blooms are difficult to observe from satellites because their potential impact on remote sensing signals is low or negligible, which is not a problem during years when Mougeotia gracillima is absent. The general trend from 2003 to 2011 satellite estimates shows a decline. The in situ data trend is not as evident because of the unusual years of 2007 and 2009. This decline may be linked to the decline in phosphorus concentration initiated in the 1970s (Schwefel et al. 2016).

The high peak years of in situ measurements (2007 and 2009) were not obvious when considering all available pixels in calculating annual PP (Fig. 6). The reasons might be the same: the phytoplankton bloom was too deep to derive with remote sensing; or the annual estimate based on the in situ measurements overestimated annual production because the single in situ measurement captured the highest PP peak, which was not typical over a longer period. The latter case is more probable because we had slightly more than 1000 cloud-free scenes over 9 years (average 114 images per year), while in situ estimates for the same period were based on 173 measurements (19 measurements per year). Fewer measurements per year give more weight to a single measurement on the yearly estimation of PP. For example, measurements during a bloom will raise the yearly estimates, but the in situ samplings just before or after the blooms lead to the underestimation of yearly PP. Remote sensing provides significantly more frequent data about the lake, and therefore important events are less likely to be missed. Consequently, our modelling results represent the actual annual PP better than, or at least as good as, the in situ estimates from a single point (center of the lake). Generally, the error in estimation of annual PP with semi-monthly, single-point measurements is $\sim 20 \%$ (Fig. 6). The error does not change much if comparing results from satellite data from Centre point and satellite data including all the available lake pixels because we removed the differences between in situ measurements and modelling. However, the overall trends (years with lower and higher PP) of the in situ and modelled estimates closely agree.

Studies on lake PP based on satellite data are rare, but PP in the Great Lakes is well studied with remote sensing (Shuchman et al. 2013, Fahnenstiel et al. 2016), and some recent studies on Lake Taihu used satellite data to 
Table 4. Some examples of different lakes by their surface areas $(S)$, mean daily primary production per surface area $\left(\mathrm{PP}_{\text {daily }}\right)$, mean annual lake primary production $\left(\mathrm{PP}_{\mathrm{yr}}\right)$, and observation period $(t)$ in years.

\begin{tabular}{|c|c|c|c|c|}
\hline & $\underset{\mathrm{km}^{2}}{\mathrm{~S}}$ & $\begin{array}{c}\mathrm{PP}_{\text {daily }} \\
\mathrm{mg} \mathrm{C} \mathrm{m}^{-2} \mathrm{~d}^{-1}\end{array}$ & $\begin{array}{c}\mathrm{PP}_{\mathrm{yr}} \\
\mathrm{Tg} \mathrm{Cyr}^{-1}\end{array}$ & $\begin{array}{c}t \\
\text { year }\end{array}$ \\
\hline Upper Great Lakes & 199718 & 261 & 19.05 & 2010-2013 \\
\hline Lake Michigan & 58030 & $401^{a}$ & 8.57 & 1998-2008 \\
\hline Lake Taihu & 2250 & 1094 & $0.89 *$ & 2003-2013 \\
\hline Lake Geneva & 580 & 828 & 0.18 & 2003-2011 \\
\hline Lake Võrtsjärv & 271 & 558 & $0.055^{\mathrm{a}}$ & 1982-2009 \\
\hline
\end{tabular}

${ }^{a}$ Converted into comparable units by authors.

estimate PP (Deng et al. 2017). For a more global picture of Lake Geneva's position among other lakes, we compared the mean annual PP for the lake $(0.18 \mathrm{Tg} \mathrm{C}$ $\mathrm{yr}^{-1}$ ) with other lakes around the world (Table 4).

If examining an entire lake as a producer of carbon, then the size of the lake is obviously an important factor. For example, the entire Upper Great Lakes (including Lakes Erie, Huron, Michigan, Ontario, and Superior, all in the top 15 largest lakes in the world) in North America are larger than Lake Geneva by a factor of 300 and have $>120$ times higher annual production, yet they have lower values for mean daily production (Fahnenstiel et al. 2016). Lake Michigan is about 2 orders of magnitude larger and has 50 times higher production than Lake Geneva (Shuchman et al. 2013). Lake Taihu (in China), known as a shallow, eutrophic, and productive lake, is almost 4 times larger than Lake Geneva and has 6 times higher production (Deng et al. 2017). The most eutrophic lake in our comparison (Table 4), the shallow Lake Vorrtsjärv in Estonia, has ice cover more than 4 months per year and productivity close to zero (Nõges et al. 2011); and the fact that the annual carbon production in Vortsjärv is lower than in Lake Geneva by the factor of 2.7 is not only caused by the size of the lake but also by the climate conditions. Therefore, depending on the subject, it would be better to describe the lake with production per unit area during a certain productive period (e.g., one summer month), not the total PP of the lake in a year.

Initially, smaller lakes seem to play a small role in the global carbon cycle; however, $\sim 117$ million lakes exist around the world, covering $\sim 5$ million $\mathrm{km}^{2}$ of the Earth (Verpoorter et al. 2014), and only about 29\% of this area is composed of the 225 biggest lakes in the world (surface area $>1000 \mathrm{~km}^{2}$ ). Moreover, their waters can be relatively poor in phytoplankton, and the photic zone comprises a relatively small portion of their total volume (Table 4). Consequently, their PP per unit of study area is relatively small. Most lakes in the world have areas $0.1-1 \mathrm{~km}^{2}$, with a global coverage of $<1$ million $\mathrm{km}^{2}$ (19\% of the total area estimated), and $36 \%$ of the lakes have a surface area 1-1000 km² ( 353 000 lakes with total area $>1.8$ million $\mathrm{km}^{2}$; Verpoorter et al. 2014). Nevertheless, relatively few smaller lakes are included in monitoring programs, which excludes a vast part of the actual productivity of the lakes in the world. Therefore, remote sensing is clearly an inevitable tool to study global carbon cycle and PP in lakes.

\section{Conclusions}

The current study comprises 2 main parts: first, the validation of a simple bio-optical PP model that requires 2 main inputs both available as satellites products (Chl- $a$ and $K_{\mathrm{d}}$ ); and the second to study the spatial and temporal productivity over a decade (MERIS 2002-2012). CoastColour processor products performed the best in Lake Geneva. Our results show that satellite products can be successfully used as input data to model primary production in lakes of mesotrophic to eutrophic productivity level. Thus, the model is also applicable in deep mesotrophic lakes, not just in shallow eutrophic lakes as has been demonstrated previously. Even reduced resolution satellite data (with $1 \times 1.2 \mathrm{~km}$ pixel size) showed significant variability in PP throughout the lake, meaning that infrequent, single-point in situ measurements are insufficient to understand the behavior of primary production in medium- to large-sized lakes (possibly leading to errors of 20\%). Despite the cloud cover limitation, the new remotely sensed Earth Observation dataflow is today more frequent than monthly to semimonthly in situ observations, and thereby less impacted by contingencies. The in situ monitoring would benefit from high frequency buoy systems, although it would still not cover the spatial variability. Therefore, the future to understanding lake systems should focus on a deeper coupling between remote sensing and high frequency in situ observation.

\section{Acknowledgements}

Authors acknowledge Thomas Danckaert and Martin Clarke for their input to this study. In situ data were provided by the Commission International pour la Protection des Eaux du Leman (CIPEL) and the Observatory of Alpine Lakes (OLA), SOERE OLA-IS, AnaEE-France, INRA of Thonon-les-Bains.

\section{Disclosure statement}

No potential conflict of interest was reported by the author.

\section{ORCID}

Tuuli Soomets (D) http://orcid.org/0000-0002-3297-6652 Alfred Wüest (D) http://orcid.org/0000-0001-7984-0368 Damien Bouffard (D) http://orcid.org/0000-0002-2005-9718 


\section{References}

Arst H, Nõges T, Nõges P, Paavel P. 2008. In situ measurements and model calculations of primary production in turbid waters. Aquat Biol. 3:19-30.

Arst H, Nõges P, Nõges T, Kauer T, Arst G-E. 2012. Quantification of a primary production model using two versions of the spectral distribution of the phytoplankton absorption coefficient. Environ Model Assess. 17:431440.

Augusto-Silva PB, Ogashawara I, Barbosa CCF, de Carvalho LAS, Jorge DSF, Fornari CI, Stech JL. 2014. Analysis of MERIS reflectance models for estimating chlorophyll- $a$ concentration in a Brazilian Reservoir. Remote Sens. 6:11689-11707.

Bastviken D, Tranvik LJ, Downing JA, Crill PC, Enrich-Prast A. 2011. Freshwater methane emissions offset the continental carbon sink. Science. 331(6013):50.

Behrenfeld MJ, Boss E, Siegel DA, Shea DM. 2005. Carbonbased ocean productivity and phytoplankton physiology from space. Global Biogeochem Cy. 19(1):GB1006.

Bergamino N, Horion S, Stenuite S, Cornet Y, Loiselle S, Plisnier P-D, Descy J-P. 2010. Spatio-temporal dynamics of phytoplankton and primary production in Lake Tanganyika using a MODIS based bio-optical time series. Remote Sens Environ. 114:772-780.

Bouffard D, Kiefer I, Wüest A, Wunderle S, Odermatt D. 2018. Are surface temperature and chlorophyll in a large deep lake related? An analysis based on satellite observations in synergy with hydrodynamic modelling and in-situ data. Remote Sens Environ. 209:510-523.

Bouffard D, Perga M-E. 2016. Are flood-driven turbidity currents hot spots for priming effect in lakes? Biogeosciences. 13:3573-3584.

Cremona F, Laas A, Nõges P, Nõges T. 2016. An estimation of diel metabolic rates of eight limnological archetypes from Estonia using high-frequency measurements. Inland Waters. 6:352-363.

Defoin-Platel M, Chami M. 2007. How ambiguous is the inverse problem of ocean color in coastal waters? J Geophys Res. 112:C03004.

Deng Y, Zhang Y, Li D, Shi K, Zhang Y. 2017. Temporal and spatial dynamics of phytoplankton primary production in Lake Taihu derived from MODIS data. Remote Sens. 9:195.

Doerffer R, Schiller H. 2007. The MERIS Case 2 water algorithm. Int J Remote Sens 28:517-535.

Doerffer R, Schiller H. 2008. MERIS lake water algorithm for BEAM MERIS algorithm theoretical basis document. Inst Coastal Res GKSS Res Center. Geesthacht, Germany. Rep. GKSS-KOF-MERIS-ATBD01, Vol. 1.

Dörnhöfer K, Oppelt N. 2016. Remote sensing for lake research and monitoring - Recent advances. Ecol Indic. 64:105-122.

Fahnenstiel GL, Sayers JM, Shuchman AR, Yousef F, Pothoven AS. 2016. Lake-wide phytoplankton production and abundance in the Upper Great Lakes: 2010-2013. J Great Lakes Res. 42:619-629.

Fee EJ. 1998. Computer programs for calculating in situ phytoplankton photosynthesis. Can Tech Report Fish Aquat Sci. 1740:ISSN-6457.

Gons HJ, Auer MT, Effler SW. 2008. MERIS satellite chlorophyll mapping of oligotrophic and eutrophic waters in the
Laurentian Great Lakes. Remote Sens Environ. 112:40984106.

Gower J, King S, Borstad G, Brown L. 2005. Detection of intense plankton blooms using the $709 \mathrm{~nm}$ band of the MERIS imaging spectrometer. Int $J$ Remote Sens. 26:2005-2012.

Holmes RW. 1970. The Secchi disk in turbid coastal zones. Limnol Oceanogr. 15:688-694.

Kauer T, Arst H, Nõges T, Tuvikene L. 2009. Estimation of the phytoplankton productivity in three Estonian lakes. Est J Ecol. 58:297-312.

Kauer T, Arst H, Nõges T, Arst G-E. 2013. Development and application of a phytoplankton primary production model for well-mixed lakes. P Est Acad Sci. 62:267-276.

Kauer T, Kutser T, Arst H, Danckaert T, Nõges T. 2015. Modelling primary production in shallow well mixed lakes based on MERIS satellite data. Remote Sens Environ. 163:253-261.

Kiefer I, Odermatt D, Anneville O, Wüest A, Bouffard D. 2015. Application of remote sensing for the optimization of insitu sampling for monitoring of phytoplankton abundance in a large lake. Sci Total Environ. 527-528:493-506.

Klemas V. 2012. Remote sensing of algal blooms: an overview with case studies. J Coast Res. 28:34-43.

Kutser T. 2004. Quantitative detection of chlorophyll in cyanobacterial blooms by satellite remote sensing. Limnol Oceanogr. 49:2179-2189.

Meinson P, Idrizaj A, Nõges P, Nõges T, Laas A. 2016. Continuous and high-frequency measurements in limnology: history, applications and future challenges. Environ Rev. 24:52-62.

Mishra S, Mishra DR. 2012. Normalized difference chlorophyll index: a novel model for remote estimation of chlorophyll- $a$ concentration in turbid productive waters. Remote Sens Environ. 117:394-406.

Morel A, Antoine D. 2011. ATBD 2.9 - Pigment index retrieval in Case 1 waters. LOV, MERIS ESL. 4

Morel A, Huot Y, Gentili B, Werdell PJ, Hooker SB, Franz BA. 2007. Examining the consistency of products derived from various ocean color sensors in open ocean (Case 1) waters in the perspective of a multi-sensor approach. Remote Sens Environ. 111:69-88.

Nõges T, Arst H, Laas A, Kauer T, Nõges P, Toming K. 2011. Reconstructed long-term time series of phytoplankton primary production of a large shallow temperate lake: the basis to assess the carbon balance and its climate sensitivity. Hydrobiologia. 667:205-222.

Odermatt D, Gitelson A, Brando VE, Schaepman M. 2012. Review of constituent retrieval in optically deep and complex waters from satellite imagery. Remote Sens Environ. 118:116-126.

Palmer SC, Kutser T, Hunter PD. 2015. Remote sensing of inland waters: challenges, progress and future directions. Remote Sens Environ. 157:1-8.

Pelletier JP. 1983. Mesure de la production primaire en milieu aquatique: problèmes méthodologiques et éléments d'interprétation [Measurement of aquatic primary production: methodological issues and interpretive elements]. Rev Fr Sci Eau. 2:339-366. French.

Platt T, Sathyendranath S. 1988. Oceanic primary production: Estimation by remote sensing at local and regional scales. Science. 241:1613-1620. 
Raymond PA, Hartmann J, Lauerwald R, Sobek S, McDonald C, Hoover M, Butman D, Striegl R, Mayorga E, Humborg C, et al. 2013. Global carbon dioxide emissions from inland waters. Nature. 503:355-359.

Reynolds CS. 2006. Ecology of phytoplankton. Cambridge (UK): Cambridge University Press.

Schroeder Th, Schaale M, Fischer J. 2007. Retrieval of atmospheric and oceanic properties from MERIS measurements: a new Case- 2 water processor for BEAM. Int J Rem Sens. 28:5627-5632.

Schwefel R, Gaudard A, Wüest A, Bouffard D. 2016. Effects of climate change on deep water oxygen and winter mixing in a deep lake (Lake Geneva) - comparing observational findings and modeling. Water Resour Res. 52:8811-8826.

Shuchman AR, Sayers M, Fahnenstiel LG, Leshkevich G. 2013. A model for determining satellite-derived primary productivity estimates for Lake Michigan. J Great Lakes Res Suppl. 39:46-54.

Siegel DA, Westberry TK, O’Brien MC, Nelson NB, Michaels AF, Morrison JR, Scott A, Caporelli EA, Sorensen JC, Maritorena S, et al. 2001. Bio-optical modeling of primary production on regional scales: the Bermuda BioOptics project. Deep-Sea Res II. 48:1865-1896.

Smith RC, Prezelin BB, Bidigare RR, Baker KS. 1989. Bio-optical modeling of photosynthetic production in coastal waters. Limnol Oceanogr. 34:1524-1544.

Spyrakos E, O’Donnell R, Hunter PD, Miller C, Scott M, Simis SG, Neil C, Barbosa CC, Binding CE, Bradt S, et al. 2018. Optical types of inland and coastal waters. Limnol Oceanogr. 63:846-870.
Stæhr PA, Markager S. 2004. Parameterization of the chlorophyll a-specific in vivo light absorption coefficient covering estuarine, coastal and oceanic waters. Int J Rem Sens. 25:5117-5130.

Steeman-Nielsen E. 1952. The use of radioactive carbon (14C) for measuring organic production in the sea. J Cons Int Explor Mer. 18:117-140.

Strickland JDH, Parsons TR. 1968. A practical handbook of seawater analysis. B Fish Res Board Can. 167.

Tranvik LJ, Downing JA, Cotner JB, Loiselle SA, Striegl RG, Ballatore TJ, Dillon P, Finlay K, Fortino K, Knoll LB, et al. 2009. Lakes and impoundments as regulators of carbon cycling and climate. Limnol Oceanogr. 54:2298-2314.

Toming K, Kutser T, Laas A, Sepp M, Paavel B, Nõges T. 2016. First experiences in mapping lake water quality parameters with Sentinel-2 MSI Imagery. Remote Sens. 8:640-654.

Verpoorter C, Kutser T, Tranvik L, Seekel D. 2014. A global inventory of lakes based on high resolution satellite imagery. Geophys Res Lett. 41:6396-6402.

Williamson CE, Brentrup JA, Zhang J, Renwick WH, Hargreaves BR, Knoll LB, Overholt EP, Rose KC. 2014 Lakes as sensors in the landscape: optical metrics as scalable sentinel responses to climate change. Limnol Oceanogr. 59:840-850.

Wetzel RG. 2001. Limnology. Lake and river ecosystems. San Diego (CA): Elsevier Academic Press.

Woźniak B, Dera J, Semovski S, Hapter R, Ostrowska M, Kaczmarek S. 1995. Algorithm for estimating primary production in the Baltic by remote sensing. Stud Mater Oceanol. 68:91-123. Polish. 